\title{
FIELD SURVEY AND NUMERICAL ANALYSIS OF 2011 TOHOKU EARTHQUAKE TSUNAMI IN THE NORTHERN PART OF MIYAGI, JAPAN
}

\author{
Tomohiro Yasuda ${ }^{1}$, Taro Kakinuma ${ }^{2}$, Takashi Tamada ${ }^{3}$ and Gozo Tsujimoto ${ }^{4}$
}

\begin{abstract}
The field survey results obtained by the team of authors in the north of Miyagi Prefecture are summarized referring to a part of the survey results by other teams of the 2011 Tohoku Earthquake Tsunami Joint Survey Group. The inundation height above sea level was measured using a laser range finder with a reflection prism. The inundation height was generally larger at bay heads, as well as cave tips, except several points, which were sheltered by a peninsula or had a tapering area. The tsunamis reached inland far away from the sea along valleys and rivers. Not only steel frame buildings but also many reinforced concrete buildings were collapsed in Onagawa Town. According to the numerical simulation, the first tsunami from the west coast and the second tsunami from the east coast should come together in Utatsusaki Peninsula, which is consistent with the interviews to survivors.
\end{abstract}

Keywords: Tsunami; post event survey; inundation height; bidirectional tsunamis

\section{INTRODUCTION}

At 14:46 JST March 11, 2011, a massive earthquake occurred off the Pacific coast of Tohoku, Japan, causing enormous tsunamis which devastated Japanese north-east coast. Its moment magnitude $M_{w}$ was 9.0 which is the 4th largest earthquake in the world since the beginning of the 20th century. About 19 thousands people were killed or missing by this disaster, which is nearly the same as the causalities $(21,920)$ by Meiji Sanriku tsunami in 1896 . More than $60 \%$ of death was caused by drowning, and $65 \%$ was over 60 years old. Miyagi Prefecture is one of the most devastated areas since epicenter is located off the Oshika peninsula, Miyagi. Inundation area in Miyagi became $327 \mathrm{~km}^{2}$, which was $89 \%$ of the total inundation area of $561 \mathrm{~km}^{2}$ as shown in Fig.1. Causalities and damaged buildings number are also large in Miyagi, meanwhile those in Iwate was the majority in the 1896 Meiji Sanriku and the 1933 Showa Sanriku tsunamis (Table 1).

Tsunami surveys were conducted by joint research groups soon after the disaster with the participation of 297 tsunami, coastal, seismology, and geology researchers from 63 universities and institutes throughout Japan (The 2011 Tohoku Earthquake Tsunami Joint Survey Group, 2011) (hereinafter denoted by JSG). The JSG consists of members from fields of natural science, tsunami engineering, coastal engineering, and tsunami related research. Tsunami inundation and runup heights were measured by the JSG, and the total numbers of survey locations are 5300. Figure 2 shows the summary of the survey results comparing with the historical tsunami records, the 1986 Meiji Sanriku $\left(M_{w} 8.5\right)$ and 1933 Showa Sanriku $\left(M_{w} 8.3\right)$ tsunamis. As shown in the figure, although the maximum runup height in the 2011 event is similar to that in the Meiji Sanriku tsunami, the affected stretch of coastline is several times larger in the Tohoku tsunami than in the Meiji Sanriku tsunami. Maximum runup heights of greater than $10 \mathrm{~m}$ are distributed along $425 \mathrm{~km}$ of coast and maximum runup heights of greater than $20 \mathrm{~m}$ are distributed along $290 \mathrm{~km}$ of coast, in direct distance. On the other hand, the vertical and horizontal distributions of runup height are similar or more intense for the 2011 Tohoku tsunami that the 2004 Indian Ocean tsunami (e.g., Karlsson et al., 2009).

Figure 3 shows the administrative districts of Miyagi Prefecture. The coast of the prefecture can be categorized into two parts. Bordering with the Oshika peninsula, the northern part is a ria coast from Kesennuma City to Oshika Peninsula and a flat plain spreads in the southern part from the west of Ishinomaki City to Yamamoto Town. A part of the trace survey results of inundation height (Mori et al., 2012) in Miyagi Prefecture is shown in Fig. 4. According to Fig. 4, inundation height is higher in the northern part due to the deeply indented, i.e., saw-tooth coastlines, where the tsunamis should be concentrated at bay heads, as well as promontory tips, while inundation area and distance from the shore are wider and longer in the southern part. Thus, we focused on northern part of Miyagi as a target area.

Tsunami trace survey in the northern part of Miyagi was conducted by us as a part of the JSG activities. This paper summarizes the field survey results and discusses the relationship between the damage and measured inundation tsunami height in the northern part of Miyagi. Numerical simulation

\footnotetext{
${ }^{1}$ Disaster Prevention Research Institute, Kyoto University, Gokasho, Uji, Kyoto 611-0011, Japan

${ }^{2}$ Kagoshima University, 1-21-40, Korimoto, Kagoshima, Kagoshima 890-0065, Japan

3 Idea Consultants Inc., 2-2-2, Hayabuchi, Tsuduki-ku, Yokohama, Kanagawa 224-0025, Japan

${ }^{4}$ Kobe City College of Technology, 8-3, Gakuen Higashi-machi, Nishi-ku, Kobe, Hyogo 651-2194, Japan
} 
was also carried out to estimate the local circumstances of tsunami which was found by the survey and interview.
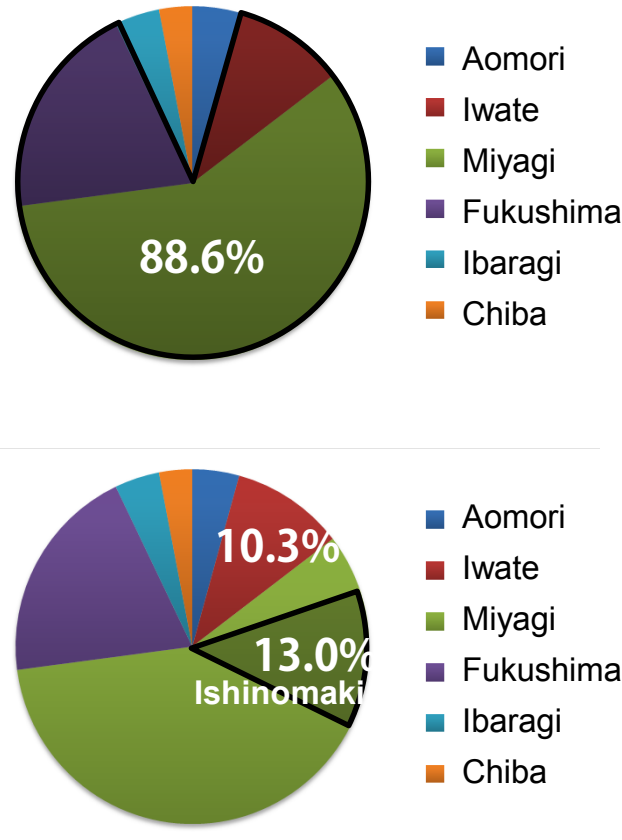

- Aomori

- Iwate

- Miyagi

- Fukushima

- Ibaragi

- Chiba

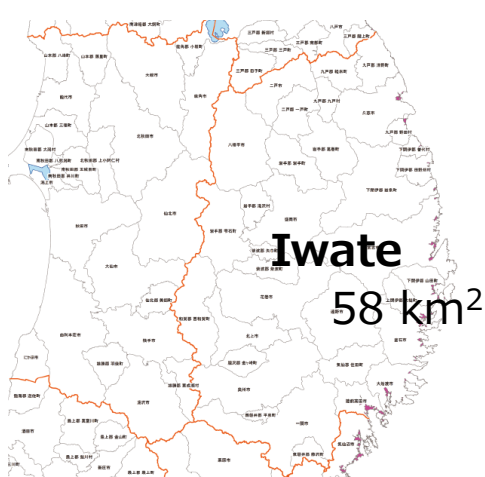

Miyagi

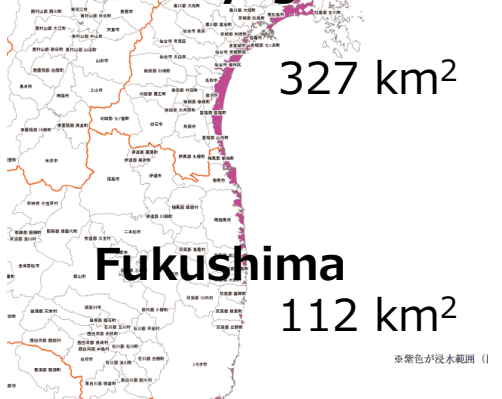

Figure 1. Inundation area caused by the 2011 Tohoku tsunami.

Table 1. Damage statistics of 2011 Tohoku, 1896 Meiji Sanriku, and 1933 Showa Sanriku tsunamis.

\begin{tabular}{|c|c|c|c|c|c|c|c|c|}
\hline & \multicolumn{3}{|c|}{2011 Tohoku } & \multicolumn{2}{|c|}{1896 Meiji Sanriku } & \multicolumn{3}{|c|}{1933 Showa Sanriku } \\
\hline & Death & Missing & $\begin{array}{l}\text { Building } \\
\text { damage }\end{array}$ & $\begin{array}{l}\text { Death and } \\
\text { Missing }\end{array}$ & $\begin{array}{l}\text { Building } \\
\text { damage }\end{array}$ & Death & Missing & $\begin{array}{l}\text { Building } \\
\text { damage }\end{array}$ \\
\hline Aomori & 3 & 1 & 1158 & 316 & 534 & 23 & 7 & 264 \\
\hline Iwate & 4664 & 1651 & 24738 & 18158 & 6036 & 1316 & 1397 & 4035 \\
\hline Miyagi & 9447 & 2141 & 166802 & 3446 & 1387 & 170 & 138 & 1474 \\
\hline $\begin{array}{l}\text { Fukushi } \\
\text { ma }\end{array}$ & 1604 & 239 & 66717 & - & - & - & - & - \\
\hline Total & 15748 & 4032 & 259415 & 21920 & 7957 & 1509 & 1542 & 5773 \\
\hline $\begin{array}{l}\text { Richter } \\
\text { scale }\end{array}$ & $y$ & $\therefore$ & . & $3 \times p$ & 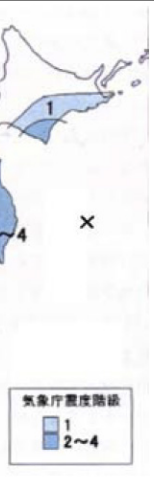 & ind & $2^{3} 4$. & 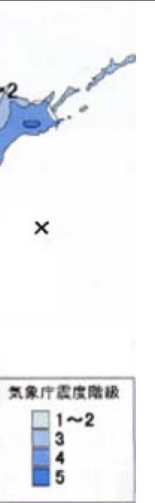 \\
\hline
\end{tabular}



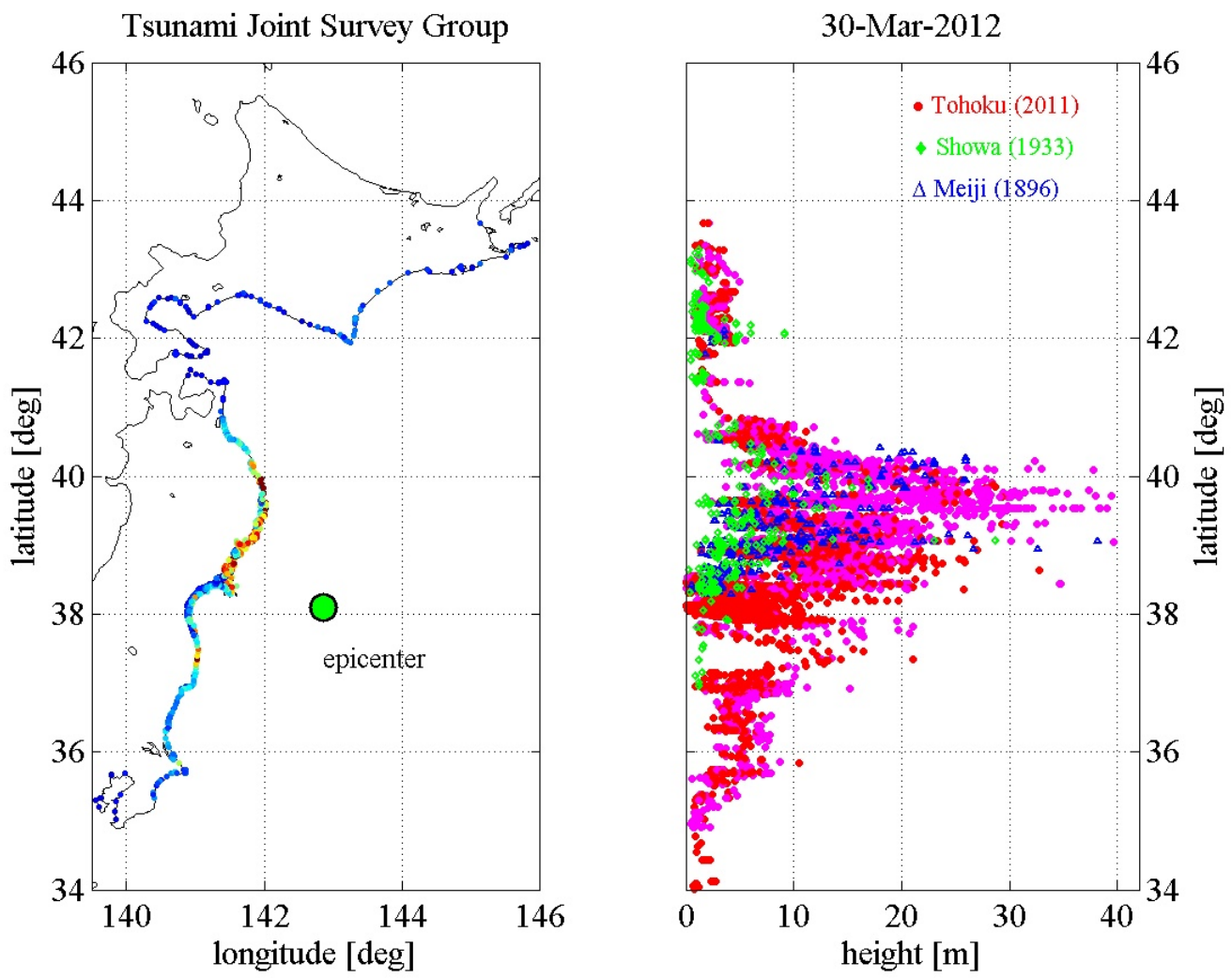

Figure 2. Measured tsunami inundation and runup heights of the 2011 Tohoku tsunami plotted versus latitude comparing with historical tsunami records (Mori et al., 2011).

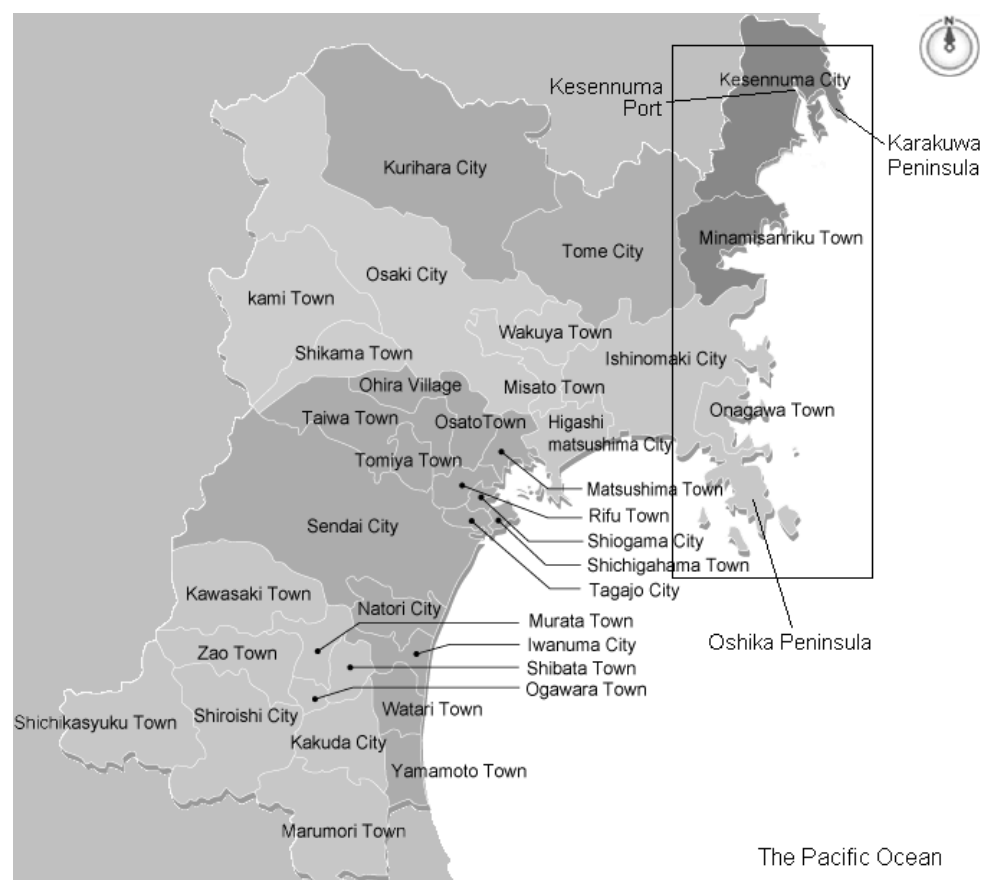

Figure 3. Administrative districts of Miyagi Prefecture. 


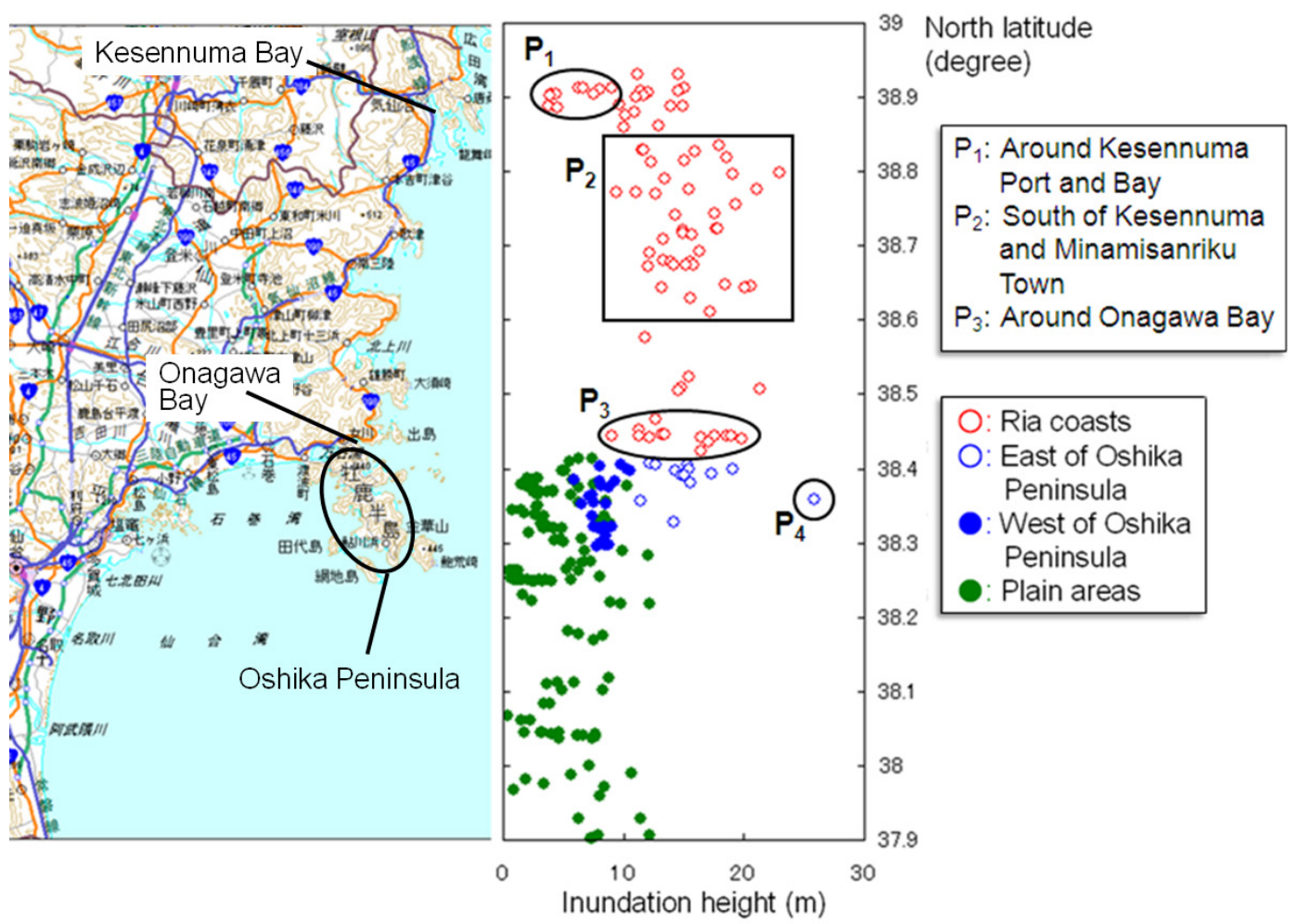

Figure 4. Distribution of inundation height in Miyagi Prefecture. The north latitude in the right-hand side graph corresponds to that in the left-hand side map. The data include a part of the trace survey results obtained by other teams of the JSG (Mori et al, 2012).

\section{FIELD SURVEY}

Field surveys were conducted in three periods: $1^{\text {st }}$ to $6^{\text {th }}$ April, $24^{\text {th }}$ to $26^{\text {th }}$ April, and $20^{\text {th }}$ to $22^{\text {nd }}$ September, 2011. A laser range finder was employed to measure tsunami trace height from the mean sea level. In the present paper, the 'inundation height' is determined as the maximum level of water surface when the water surface is estimated not to have reached the maximum level quite locally and instantaneously but to have been kept at the level for a while; the unit of inundation height is meter over Tokyo Peil (T.P.), i.e., the standard mean sea level in Tokyo Bay.

\section{Kesennuma City}

Around Kesennuma Port, although the low-ground area was damaged, the inundation height showed rather low level between 3 and $9 \mathrm{~m}$, which are indicated by plots circled with Ellipse P1 in Fig. 4, because the port was behind the Karakuwa Peninsula as shown in Fig. 3. Photo 1 shows a fishing boat with a car, which ran into a house near a port wharf.

The distribution of inundation height in both the south of Kesennuma City and Minamisanriku Town is shown in Fig. 5. The inundation height was generally larger at bay heads due to concentration of the tsunami energy, as well as promontory tips through refraction of tsunami waves.

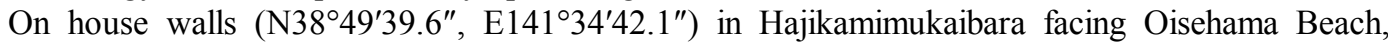
indicated in the square area Q1 in Fig. 5, tsunami trace lines were marked clearly at the level $16.0 \mathrm{~m}$ above sea level. Photo 2 shows houses around there: the second floor of the right-hand side house was swept for a horizontal distance of approximately $50 \mathrm{~m}$ to come into collision with the left-hand side house, the foundation level of which was higher than that of the swept house by 2 or $3 \mathrm{~m}$. The house is about $400 \mathrm{~m}$ away from the coastline as the crow flies, where the distance from a coastline is described as the direct distance between the place and the coast nearest to it in the present paper. 


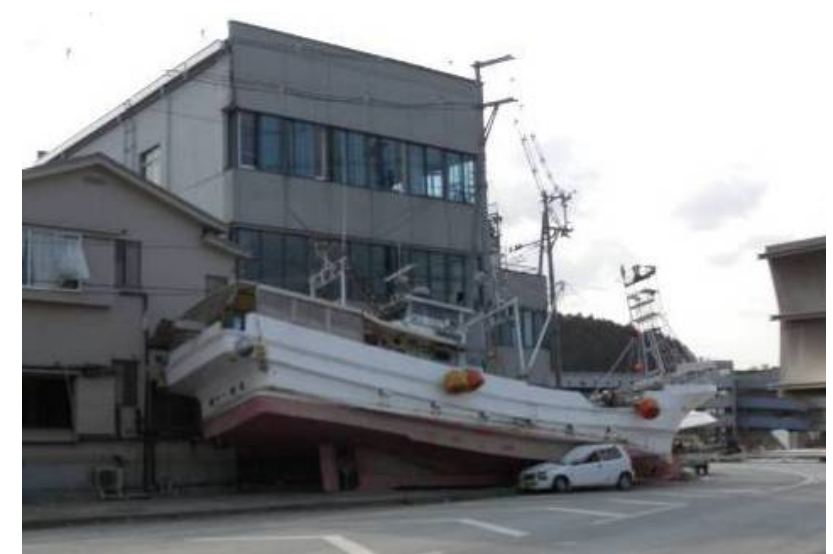

Photo 1. Fishing boat stranded on a road facing Kesennuma Port (The photo was taken on April 2, 2011.).

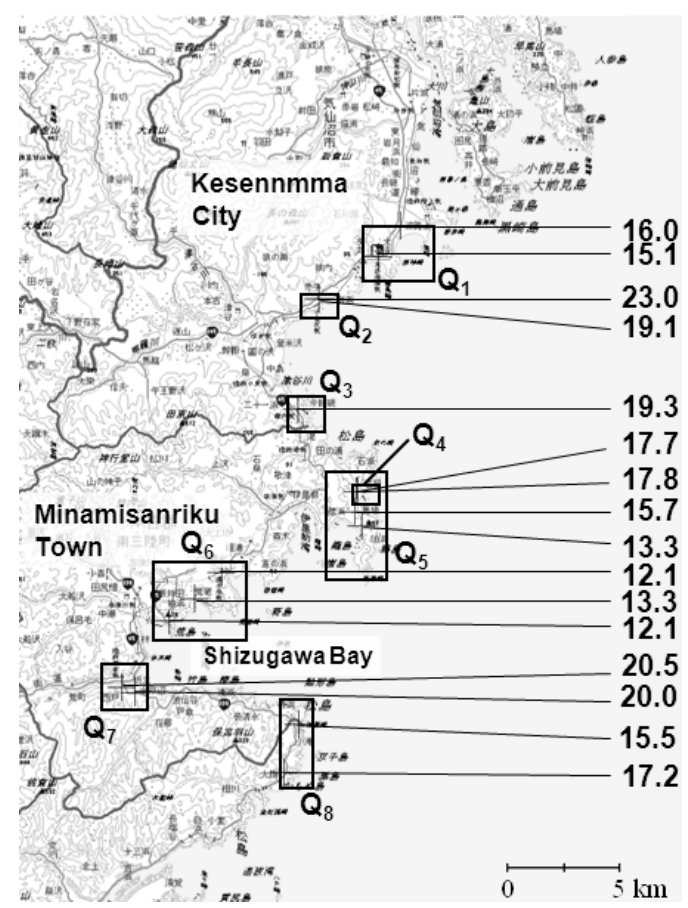

Figure 5. Distribution of inundation height measured by the authors in both the south of Kesennuma City and Minamisanriku Town (unit: $\mathrm{m}$ ).

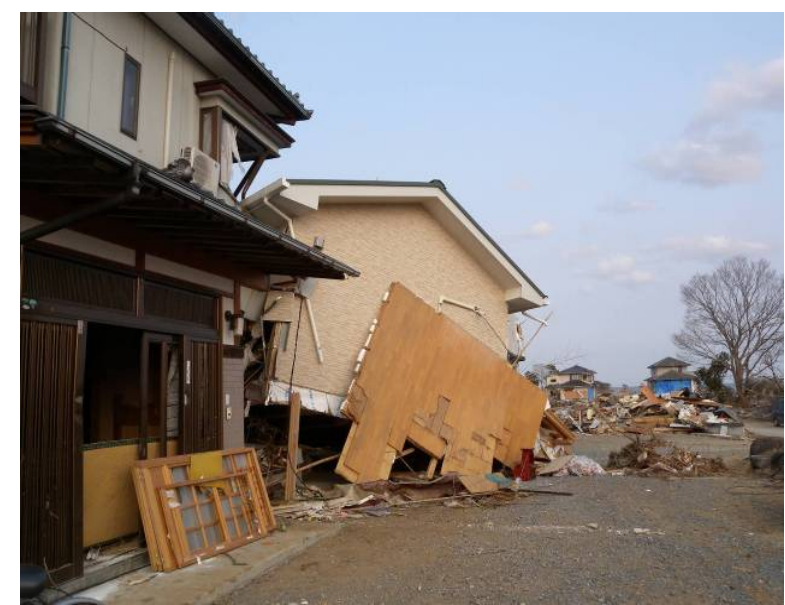

Photo 2. Damaged houses in Hajikamimukaibara, where the left-hand side house was collided with the second floor of the right-hand side house (The photo was taken on April 2, 2011.). 


\section{Motoyoshi Town}

The sandy beaches of both Oisehama Beach and Ooyakaigan Coast seem to have lost sand zones about $50 \mathrm{~m}$ wide in the cross-shore direction by comparing before with after the tsunami event possibly due to subsidence of ground or erosion by tsunamis; the satellite photographs of Oisehama Beach before and after the tsunami attack are shown in Fig. 6.

Inside the hall of Atago Shrine (N38 47'55.6", E141 $\left.{ }^{\circ} 32^{\prime} 12.1^{\prime \prime}\right)$ in Akaushi in the area Q2 in Fig. 5, there were distinct trace lines at the level $23.0 \mathrm{~m}$ above sea level, where Atago Shrine was on a hill as shown in Photo 3, about $180 \mathrm{~m}$ away from the shoreline.

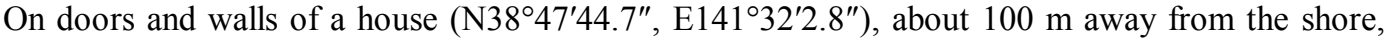
behind Koganezawa Station on Kesennuma Line of East Japan Railway Company, trace lines were plainly drawn at the level $19.1 \mathrm{~m}$ above sea level. The horizontal distance between Atago Shrine and Koganezawa Station was less than $400 \mathrm{~m}$; nevertheless the difference in inundation height between them is significant, i.e., $3.9 \mathrm{~m}$. Atago Shrine was located on a hill in a tapering area and the tsunamis should become higher through runup or reflection on the hill cliff.

On walls and windows of a house (N38 $45^{\prime} 18.3^{\prime \prime}$, E141 $\left.31^{\prime} 34.2^{\prime \prime}\right)$ in Utou in the area Q3 in Fig. 5, clear trace lines were remained at the level $19.3 \mathrm{~m}$ above sea level and about $200 \mathrm{~m}$ away from the shoreline. Kurauchi Fishing Port was protected by breakwaters against wind waves but the breakwater height was too low to hinder the higher and longer tsunamis from propagating towards the land.
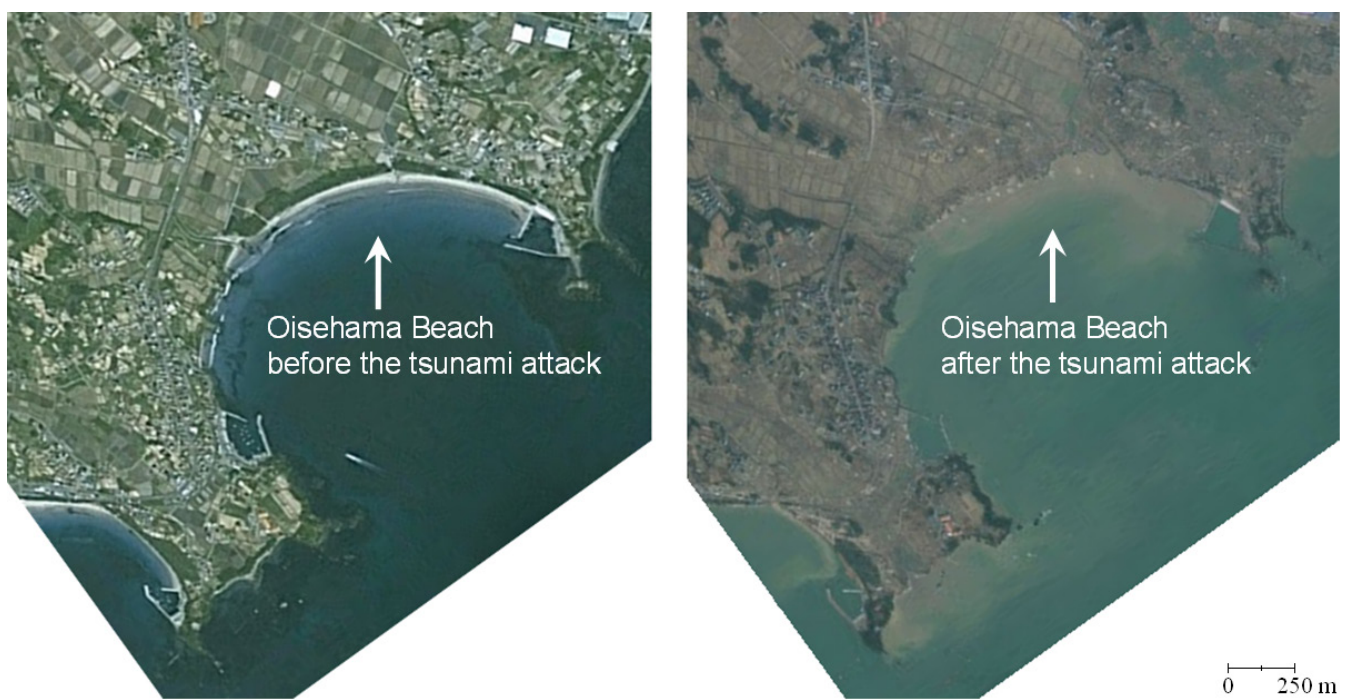

Figure 6. Satellite photographs of Oisehama Beach before and after the tsunami attack (๑) 2010 Google, ( 2011 Cnes/Spot Image, Image @ 2011 TerraMetrics).

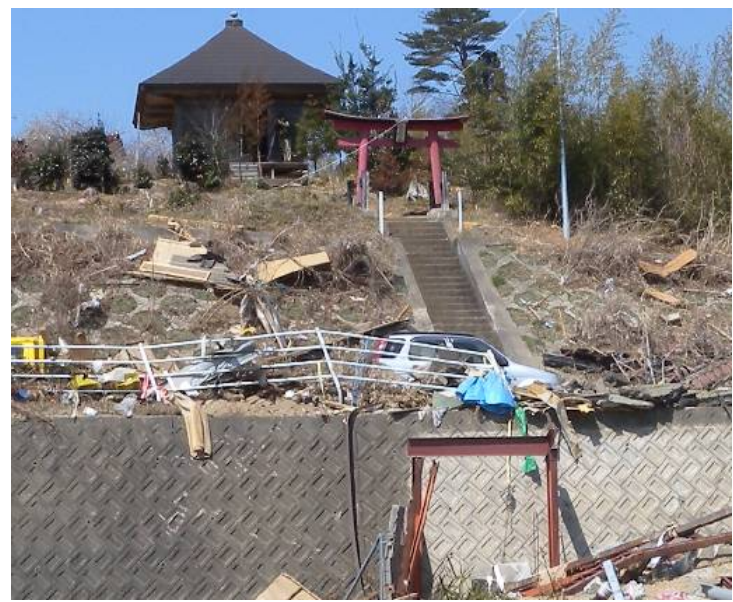

Photo 3. Atago Shrine (N3847'55.6", E141 ${ }^{\circ} 32^{\prime} 12.1^{\prime \prime}$ ) in Akaushi (The photo was taken on April 5, 2011.). 


\section{Minamisanriku Town}

A sign board showing the inundation level was put on a private-house fence (N38 $43^{\prime} 20.6^{\prime \prime}$, E141 $\left.{ }^{\circ} 33^{\prime 2} 2.3^{\prime \prime}\right)$ by an inhabitant of the house on the east of Natari Elementary School, which located in the area Q4 in Fig. 5. The top edge of the plate was at the level $17.7 \mathrm{~m}$ above sea level and about $170 \mathrm{~m}$ away from the coast. After the attack of the 1933 Showa Sanriku Tsunami, he and his neighbors had moved out their low-ground residential areas to higher hills, where they must cut down tall cedars, such that his house was only flooded just above floor level without breakage.

On a door and walls of a pet house of Natari Elementary School (N38 43'20.4", E141 33'20.6"), distinct trace lines were drawn at the level $17.8 \mathrm{~m}$ above sea level and about $200 \mathrm{~m}$ away from the shore, which is consistent with the inundation level at the house of eyewitness. The athletic field, which was at the same level as the foundation of the school buildings and lower than that of the pet house, was designated as an evacuation site for the local residents against tsunamis but the level is about $6 \mathrm{~m}$ lower than the actual inundation height.

The area Q5 around Utatsusaki Peninsula in Fig. 5 is magnified in Fig. 7. The inundation height at Point (1) (N38 $42^{\prime} 52.4^{\prime \prime}$, E141 $\left.33^{\prime} 17.8^{\prime \prime}\right)$ in Fig. 7 was just over the plum trees on a cliff slope according to the interview with survivors and a lot of remained debris at the level. It was $15.7 \mathrm{~m}$ above sea level, about $290 \mathrm{~m}$ away from the coastline. The affected family, whose house has been washed away, never imagined that the tsunamis would reach their house when they were staying out of doors at the level of the house foundation more than $10 \mathrm{~m}$ higher than the local mean sea level. They were listening to the tsunami warning through a community broadcast, which said that Japan Meteorological Agency forecasted the tsunami height to be $6 \mathrm{~m}$. This episode warns the lack of current tsunami warning system which misleads the citizens. Although the predicted tsunami height was changed to $10 \mathrm{~m}$ before the tsunami runup, the family could not get the updated information because of the crash of the community broadcast system. After they watched approaching tsunami, they assumed it must be higher than expected, and they quickly evacuated to higher ground behind their house. From the elevated spot, they saw the flat water surface from below to offshore for about 20 minutes. Their house was lost in the tsunamis even though their ancestors had moved to the higher place after the 1896 Meiji Sanriku Tsunami. The family was friendly through our interview and looked energetic to blaze a new path to the future.

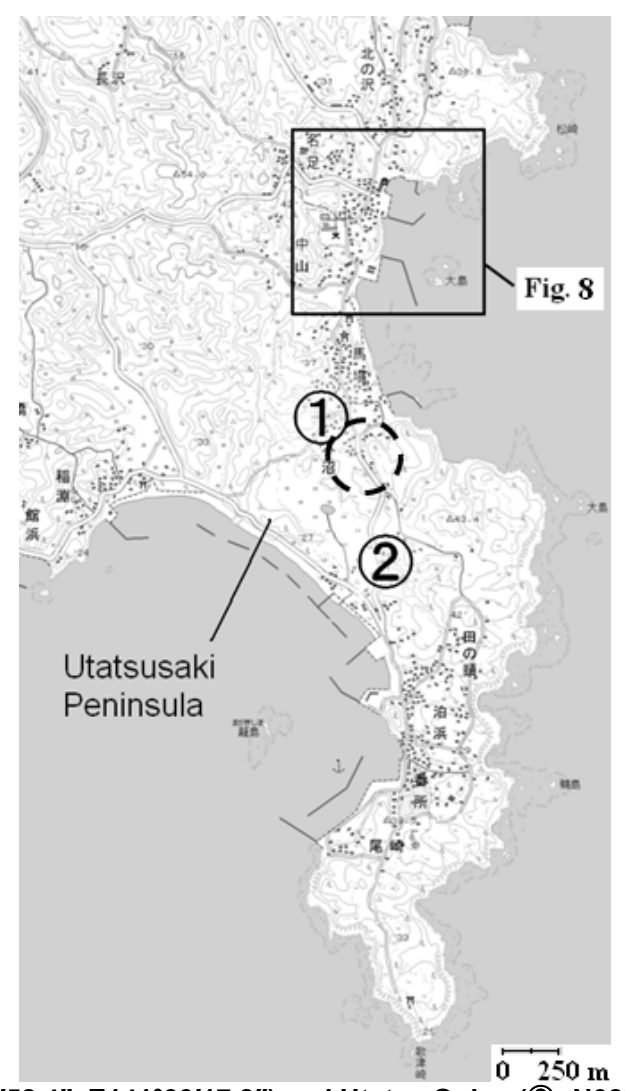

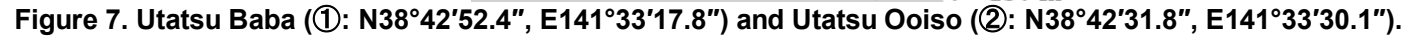


The family also observed that in some distance the water surface rose roughly $4 \mathrm{~m}$ higher than the water surface below; the place is indicated by a dashed circle in Fig. 7. From this place, a panoramic photo, i.e., Photo 4 was taken to show both the east and west sides of Utatsusaki Peninsula. Several survivors told that bidirectional tsunamis came together from both the east and west coasts of the peninsula, which will be examined through numerical computation in a later section.

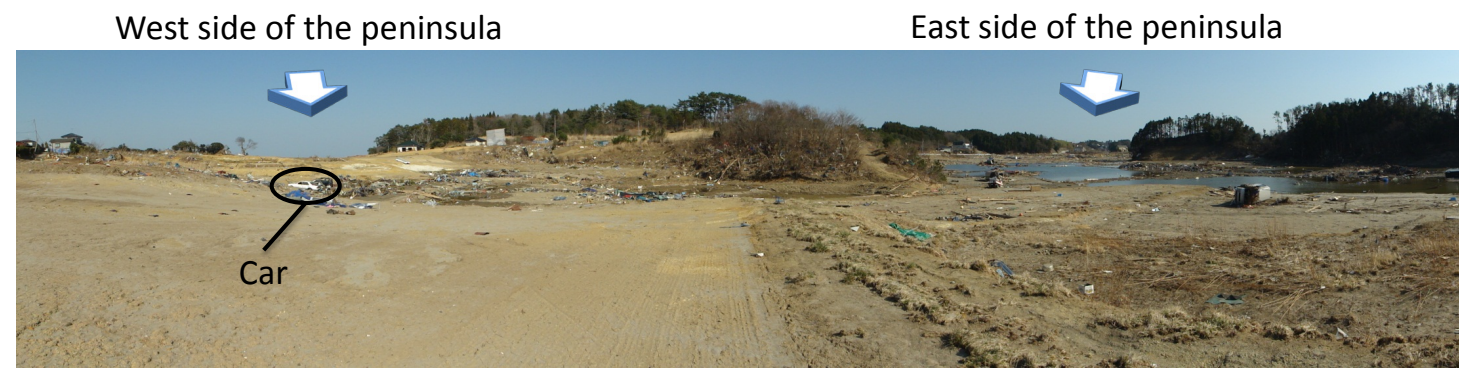

Photo 4. Panoramic view in Utatsusaki Peninsula (The photo was taken on April 5, 2011.).

\section{Shizugawa Area}

The flooded area in Shizugawa has been in ruins remaining only several reinforced concrete buildings including Shizugawa Public Hospital as shown in Photo 5, where steel frame buildings revealed their fragility. Especially along rivers, the tsunamis mercilessly reached inland far away from the sea: a lot of debris was left at the foot of a hill (N38 41'34.2', E141 $\left.25^{\prime} 45.3^{\prime \prime}\right)$ along Route 398, which paralleled a river. The maximum runup level was roughly $18 \mathrm{~m}$ above sea level through a GPS receiver and about $2.5 \mathrm{~km}$ away from the coast.

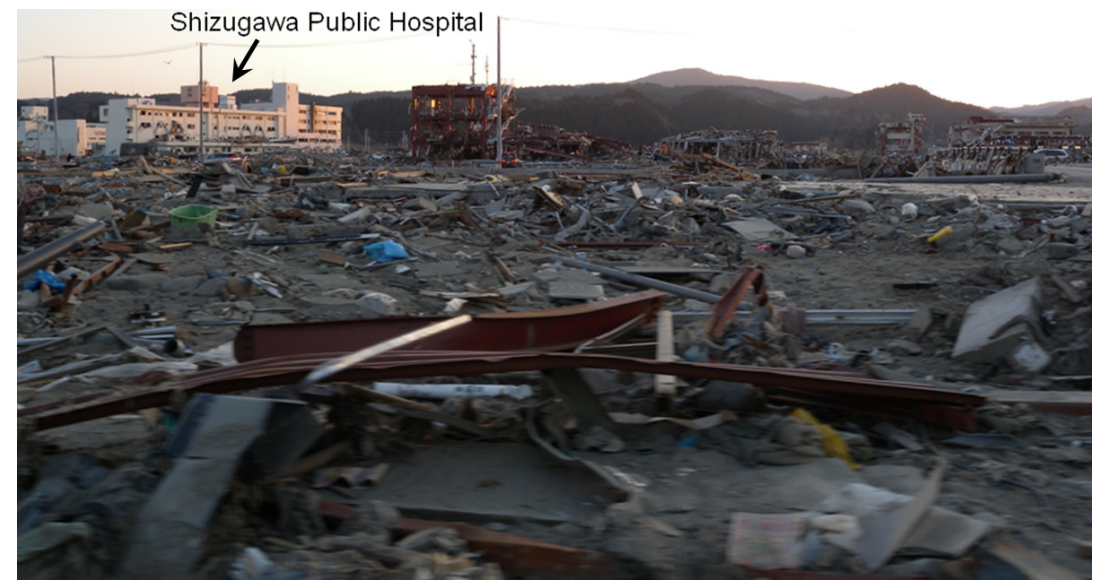

Photo 5. View of Shizugawa on April 5, 2011.

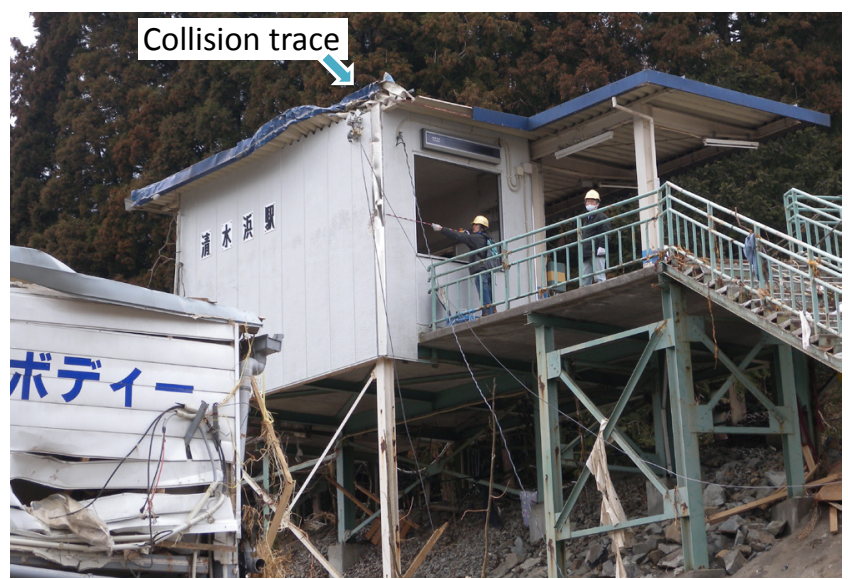

Photo 6. Tsunami traces on the building of Shizuhama Station (The photo was taken on April 3, 2011.). 
There were trace lines remained clearly on walls of Shizuhama Station on Kesennuma Line as shown in Photo 6, which is located in the area Q6 in Fig. 5. The trace lines of the station were at the level $12.1 \mathrm{~m}$ above sea level and about $260 \mathrm{~m}$ away from the shore. The tsunami height was over the level of railways, such that Kesennuma Line was heavily damaged: its railway concrete bridges were fallen possibly due to not only horizontal but also uplift force. Iron rails could not be cut easily, resulting in their bending or falling.

\section{Togura Area}

Clear trace lines were remained on windows of a house (N38 $38^{\prime} 41.1^{\prime \prime}$, E141 $\left.26^{\prime} 12.1^{\prime \prime}\right)$ located on the west side hill at Togura, in the area Q7 in Fig. 5, which level was $20.5 \mathrm{~m}$ above sea level and about $450 \mathrm{~m}$ away from the coast. According to an interview to a person who was carried by the tsunami flow for approximately $300 \mathrm{~m}$ off Togura, many persons had such experiences: another person who promptly rode on a roof of a floating house to take refuge was flown offshore until he was rescued by a fishing boat in the night of that day.

Trace lines were distinctly drawn on the ground-floor windows of Togura Junior High School (N38 $\left.38^{\prime} 33.9^{\prime \prime}, 141^{\circ} 26^{\prime} 35.6^{\prime \prime}\right)$, where the inundation height was at the level $20.0 \mathrm{~m}$ and about $70 \mathrm{~m}$ away from the shoreline. Togura Junior High School was located on the south side hill of the town. The moai statues were built at the foot of the hill as the memory of the 1960 Chilean Earthquake Tsunami as shown in the right-hand side photo of Fig. 8. The maximum 'inundation depth' at the junior high school was only $1.7 \mathrm{~m}$, while Togura Elementary School stood at the low-lying area in the middle of the town district as shown in the contour map of Fig. 8, which resulted in oyster shells left on the rooftop of the three-storied building of the elementary school due to the tsunamis as shown in Photo 7.

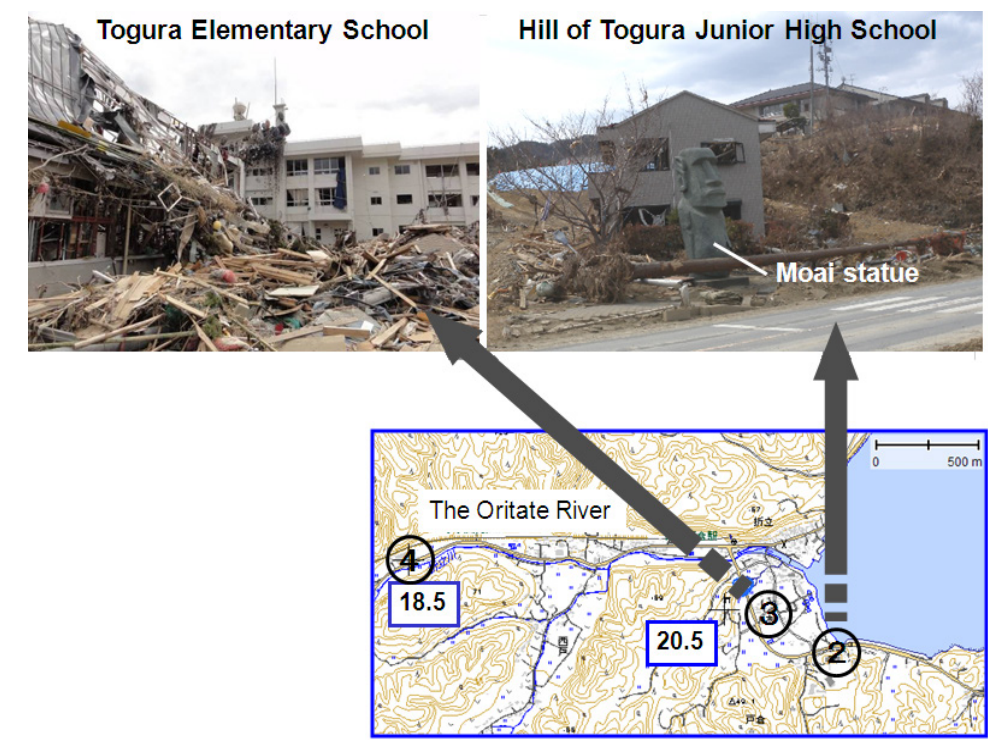

Fig. 8. Two public schools in Togura (The photos were taken on April 3, 2011. The unit of inundation height in the map is meter.).
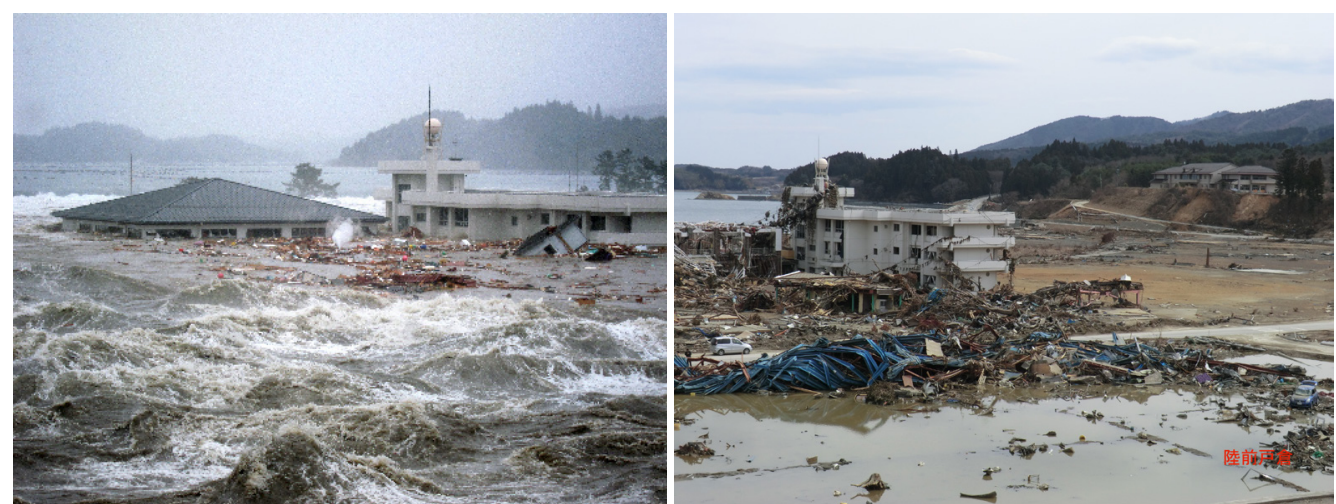

Photo 7. Situation of Togura Elementary School on March 11, 2011 and perspective of two public schools in Togura (Left photo was taken by a resident and right photo was taken by the authors on April 3, 2011.). 
It should be noted that parapets of coastal seawalls were left near the elementary school, which means that they were flown and delivered for about $100 \mathrm{~m}$ from the coastline. Along the Oritate River, the inundation height showed a large value even inland, i.e., $18.5 \mathrm{~m}$ above sea level at Point (4) in the map of Fig. 8 about $2 \mathrm{~km}$ away from the river mouth.

\section{Onagawa Town}

The inundation height was high through the coast around Onagawa Bay as shown by the plots circled with Ellipse P3 in Fig. 3, such that Onagawa Town was one of the most damaged places due to the tsunamis. The distribution of inundation height in the town is shown in Fig. 9. The Onagawa Town Hospital located at the center of Circle A shown in Fig. 9 was built on a hill at the level about $16 \mathrm{~m}$ above sea level, such that only the ground floor was inundated by the tsunamis, where the maximum inundation depth was $2.0 \mathrm{~m}$.

One of the significant features of damage in Onagawa Town was collapse of many reinforced concrete buildings, which are mentioned also in Suppasri et al. (2012) and Mikami et al. (2012). An example is shown in Photos 8 and 9: Building A was toppled and carried as shown in Photo 8 and the bottom of its foundation was revealed as shown in Photo 9 with foundation piles pulled out. The Buildings A, B, and C are in Circle B on the map of Fig. 9. The reason why Building B behind Building C, i.e., the north wing of Marinpal Onagawa, which was a facility for sightseeing and shopping, survived is not clear without information on conditions of structure, foundation, etc. but such a robust building as Building $\mathrm{C}$ is expected to play a role of a barrier to reduce tsunami force and current. It should be noted, however, that large velocity can be developed in a narrow space between strong structures as a big tsunami passes, resulting in, for example, local scouring between the north and south wings of Marinpal Onagawa as shown in Photo 10.

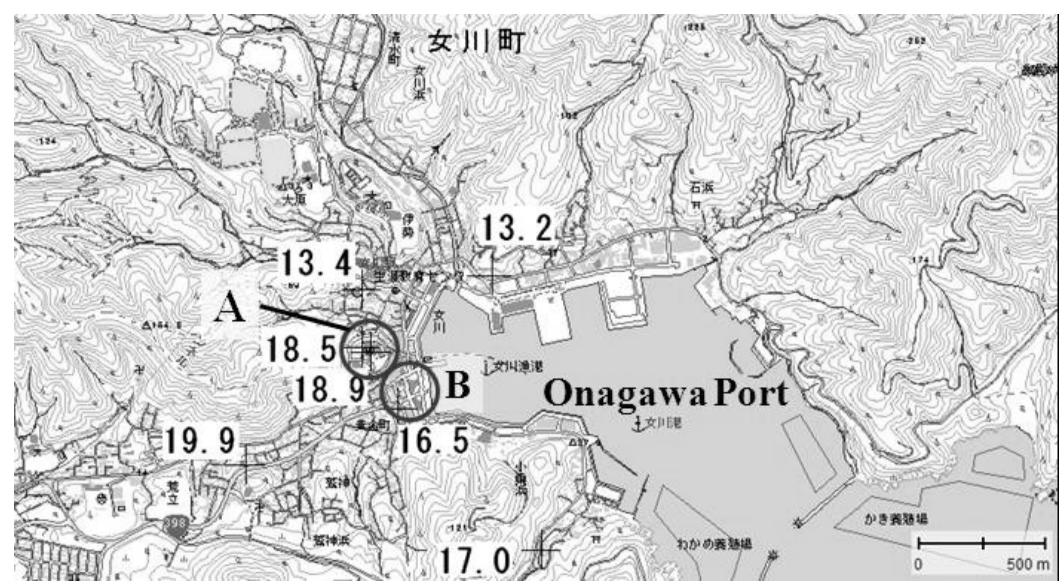

Fig. 9. Distribution of inundation height in Onagawa Town (The unit of inundation height is meter.).

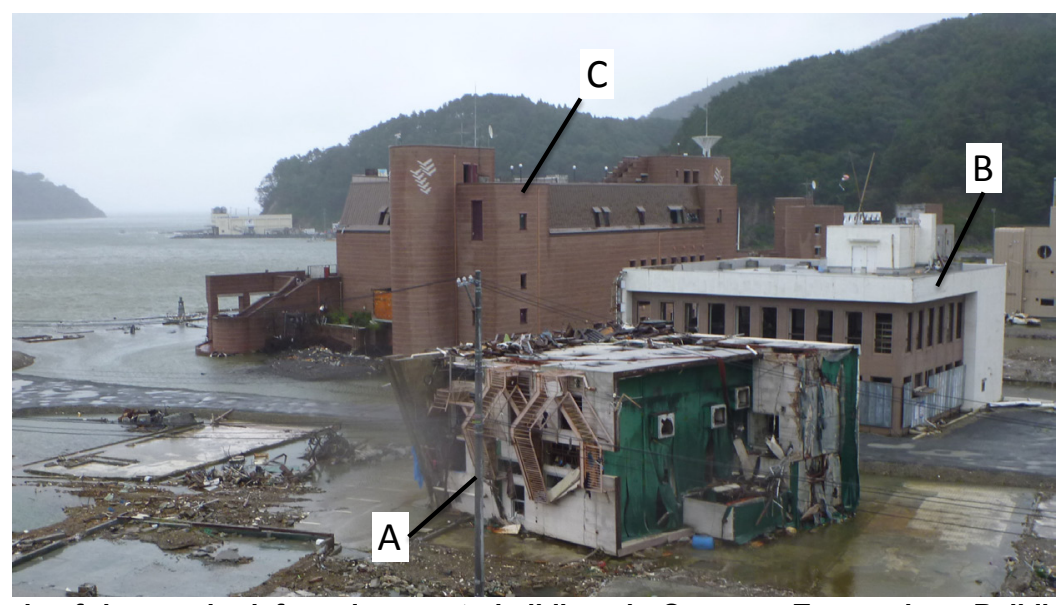

Photo 8. Example of damaged reinforced concrete buildings in Onagawa Town, where Building A is toppled down not behind Building C, i.e., the north wing of Marinpal Onagawa (The photo was taken on September 21, 2011.). 


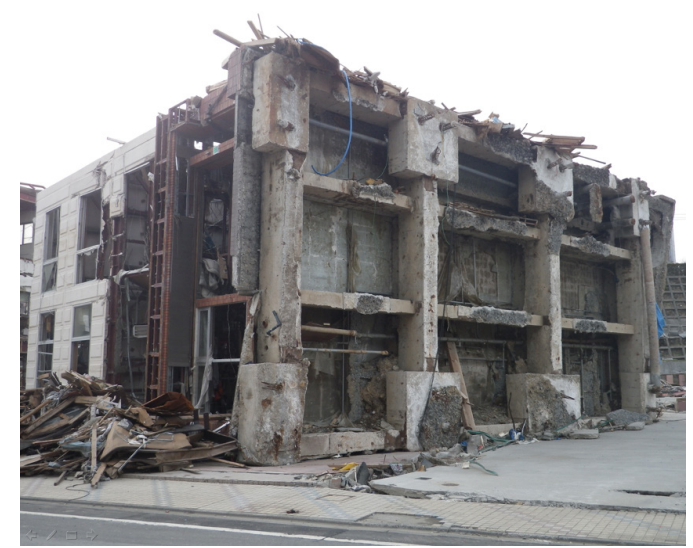

Photo 9. Foundation bottom of Building A in Photo 10 (The photo was taken on April 26, 2011.).

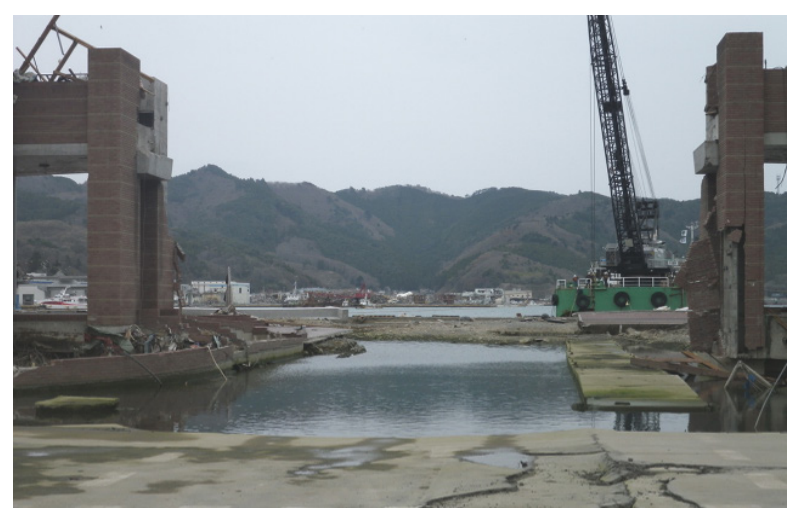

Photo 10. Local scouring between two wings of Marinpal Onagawa (The photo was taken on April 26, 2011.).
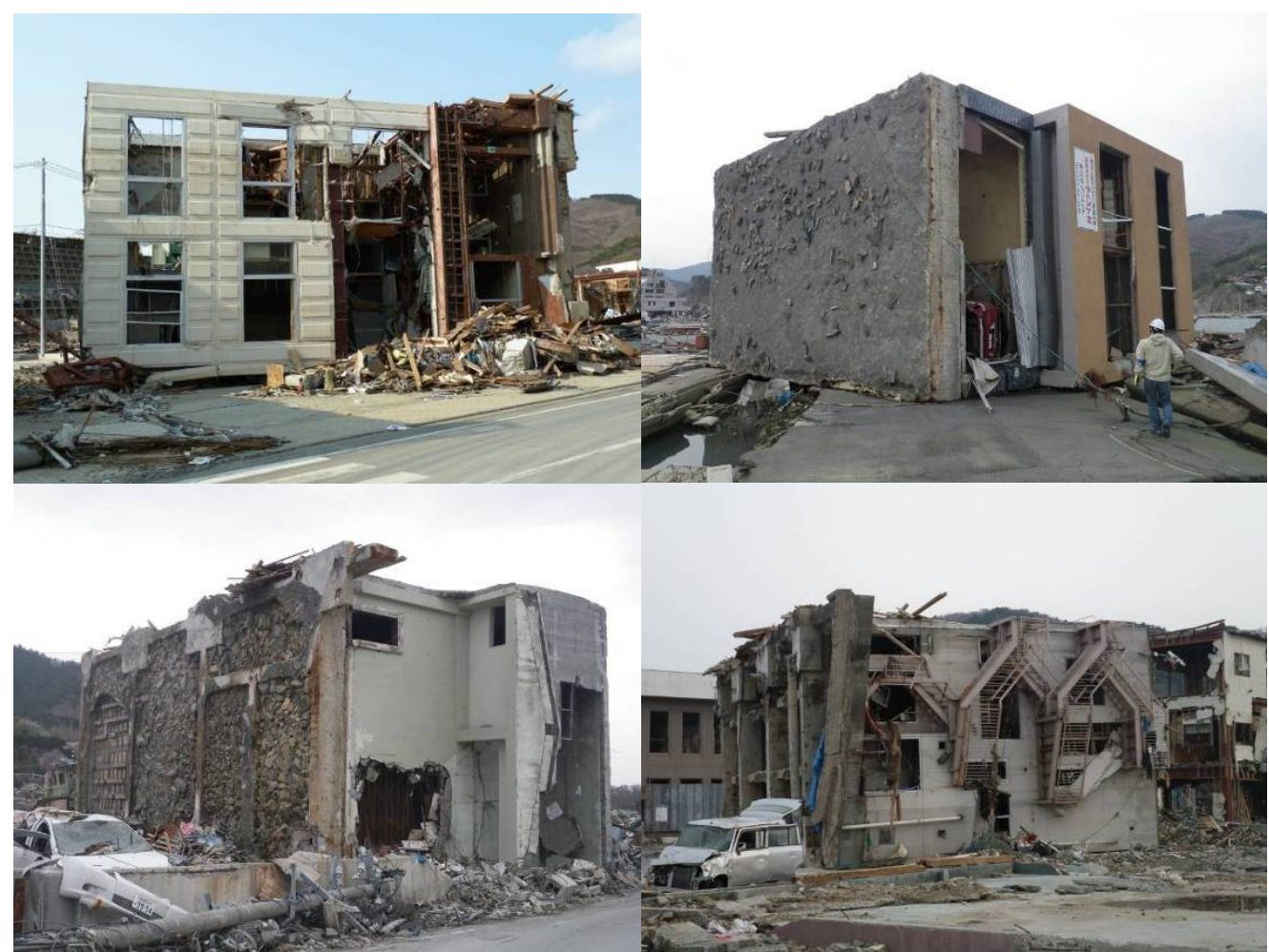

Photo 11. Examples of reinforced concrete buildings collapsed in Onagawa Town (The photos were taken on April 26, 2011.). 
Other examples of reinforced concrete buildings collapsed in Onagawa Town are introduced in Photo 11. Reinforced concrete buildings are often used as shelters; in fact the south wing of Marinpal Onagawa was designated as an evacuation building against tsunamis but the huge tsunamis propagated over it. Future work is required to elucidate the mechanism of fall or collapse of structures due to seismic oscillations, soil liquefactions, forces of repeating water current, sand motions, and aging of the structures.

\section{NUMERICAL SIMULATION}

Several survivors observed tsunamis coming together from both the east and west coasts of Utatsusaki Peninsula as mentioned in the previous section. The bidirectional-tsunami propagation over the peninsula has been simulated through a numerical model based on nonlinear shallow water equations. Four computation domains of different mesh resolution, i.e., $1350 \mathrm{~m}, 450 \mathrm{~m}, 150 \mathrm{~m}$, and $50 \mathrm{~m}$, are nested in that order. The initial profile of water surface over dislocation is assumed to be the same as the permanent shift of seabed calculated through the method of Mansinha and Smylie (1971) using the fault model presented by Tohoku University (Imamura et al., 2011). The fault is divided into ten segments as shown in Fig. 10, where the length, width, strike, dip, and rake of all the segments are $100 \mathrm{~km}, 100 \mathrm{~km}$, $193^{\circ}, 14^{\circ}$, and $81^{\circ}$, respectively. The other parameters are shown in Table 2 . The bottom friction is treated by choosing Manning's roughness between $0.025 \mathrm{~m}^{-1 / 3} \mathrm{~s}$ and $0.04 \mathrm{~m}^{-1 / 3} \mathrm{~s}$ considering the land use. The dry and wet model by Iwasaki and Mano (1979) is utilized to simulate tsunami runup. The time development is carried out using the leap-frog finite difference scheme with the staggered Arawaka Cgrid (Arakawa and Lamb, 1977). The time interval $\Delta t$ is equal to $0.5 \mathrm{~s}$ satisfying the Courant number condition.

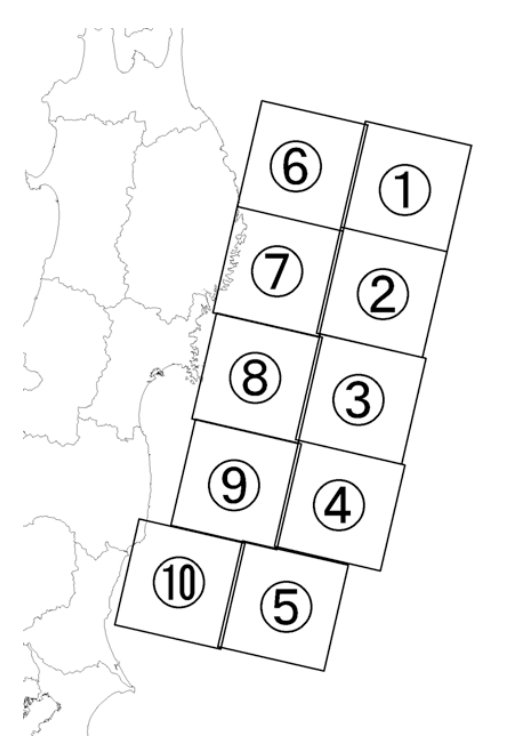

Table 2. Parameters of the fault model

(Imamura et al., 2011).

\begin{tabular}{|c|c|c|c|c|}
\hline No. & $\begin{array}{c}\text { Latitude } \\
\left({ }^{\circ} \mathrm{N}\right)\end{array}$ & $\begin{array}{c}\text { Longitude } \\
\left({ }^{\circ} \mathrm{E}\right)\end{array}$ & $\begin{array}{l}\text { Slip } \\
(\mathrm{m})\end{array}$ & $\begin{array}{c}\text { Depth } \\
(\mathrm{km})\end{array}$ \\
\hline 1 & 40.168 & 144.507 & 20.0 & \multirow[t]{5}{*}{1.0} \\
\hline 2 & 39.300 & 144.200 & 10.0 & \\
\hline 3 & 38.424 & 143.939 & 35.0 & \\
\hline 4 & 37.547 & 143.682 & 15.0 & \\
\hline 5 & 36.730 & 143.070 & 2.5 & \\
\hline 6 & 40.367 & 143.394 & 1.0 & \multirow[t]{5}{*}{24.2} \\
\hline 7 & 39.496 & 143.100 & 3.0 & \\
\hline 8 & 38.620 & 142.853 & 4.0 & \\
\hline 9 & 37.744 & 142.609 & 2.0 & \\
\hline 10 & 36.926 & 142.009 & 2.0 & \\
\hline
\end{tabular}

Fig. 10. Segments of the fault model (Imamura et al., 2011).

The calculation result of water surface displacement at the position of North Miyagi GPS Buoy is shown in Fig. 11 in comparison with the observed data through the GPS buoy (Kawai et al., 2011), where the buoy was located at the point (N38 $51^{\prime} 28^{\prime \prime}$, E141 $\left.{ }^{\circ} 53^{\prime} 40^{\prime \prime}\right)$ and the water depth was about 160 $\mathrm{m}$. Calculation results of time variation in water level at Points 1-10 in Fig. 12 are shown in Fig. 13, according to which the maximum inundation depth is larger than $10 \mathrm{~m}$ at Points $1,2,3,6,8,9$, and 10 . The first peak reaches the east coast of the peninsula and passes over Points 1-6, after that the inundation depth is $1.7 \mathrm{~m}$ at Point 7 , where no tsunami has come yet from the west coast. About 7 minutes later than the first peak appears at Point 1, Points 8-10 on the west coast are attacked by the tsunami coming from the west or south, while the second peak appears at the east coast and travels towards the southwest. Then the first tsunami from the west coast and the second tsunami from the east coast come together around Point 3 or 4 , which is consistent with the interviews, although the 
calculation results depend on the fault model. The distribution of the maximum calculated inundation height in the area of Fig. 12 during the tsunami event is shown in Fig. 14, where the maximum inundation height is between 15 and $20 \mathrm{~m}$ in the area and higher on the east than on the west of the watershed of peninsula, which agrees with the field survey results referring to the interviews to survivors.

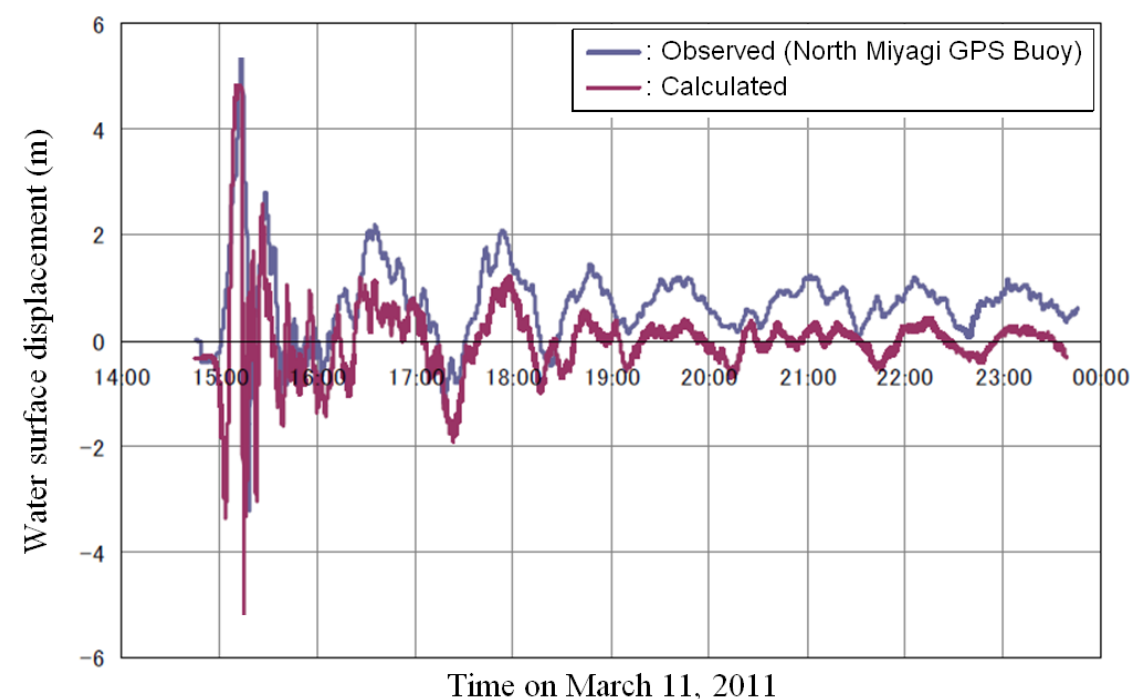

Fig. 11. Numerical result of water surface displacement at the position of North Miyagi GPS Buoy in comparison with the observed data through the GPS buoy (Kawai et al., 2011).

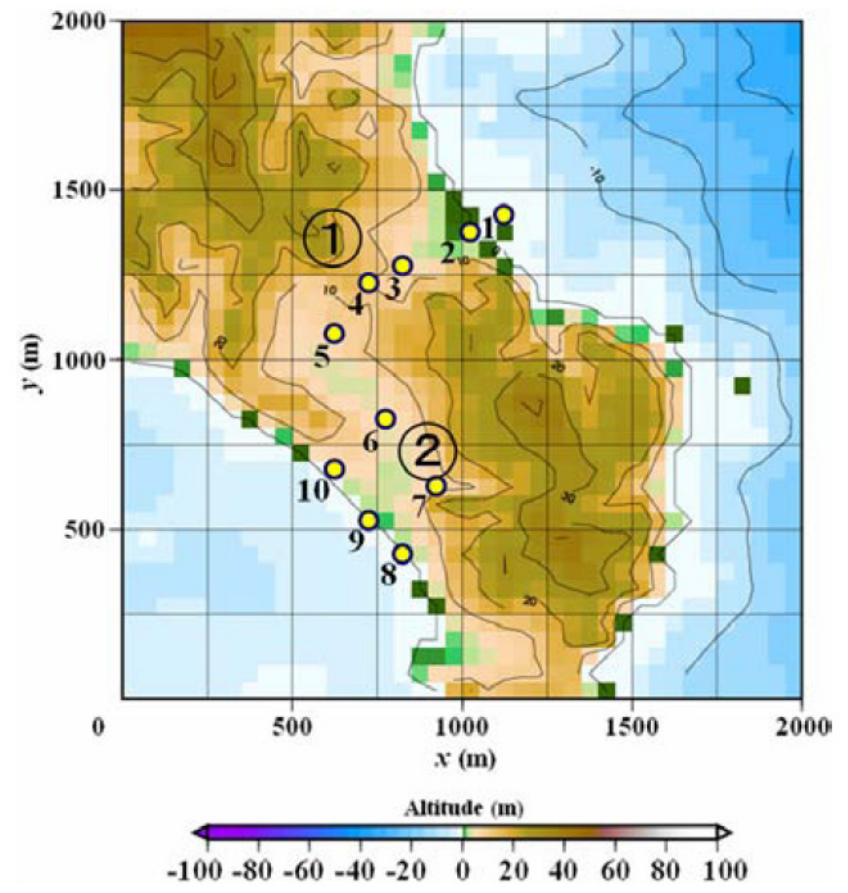

Fig. 12. Altitude in a part of Utatsusaki Peninsula. Points (1) and (2) are the same places as those in Fig. 7 in that order. 


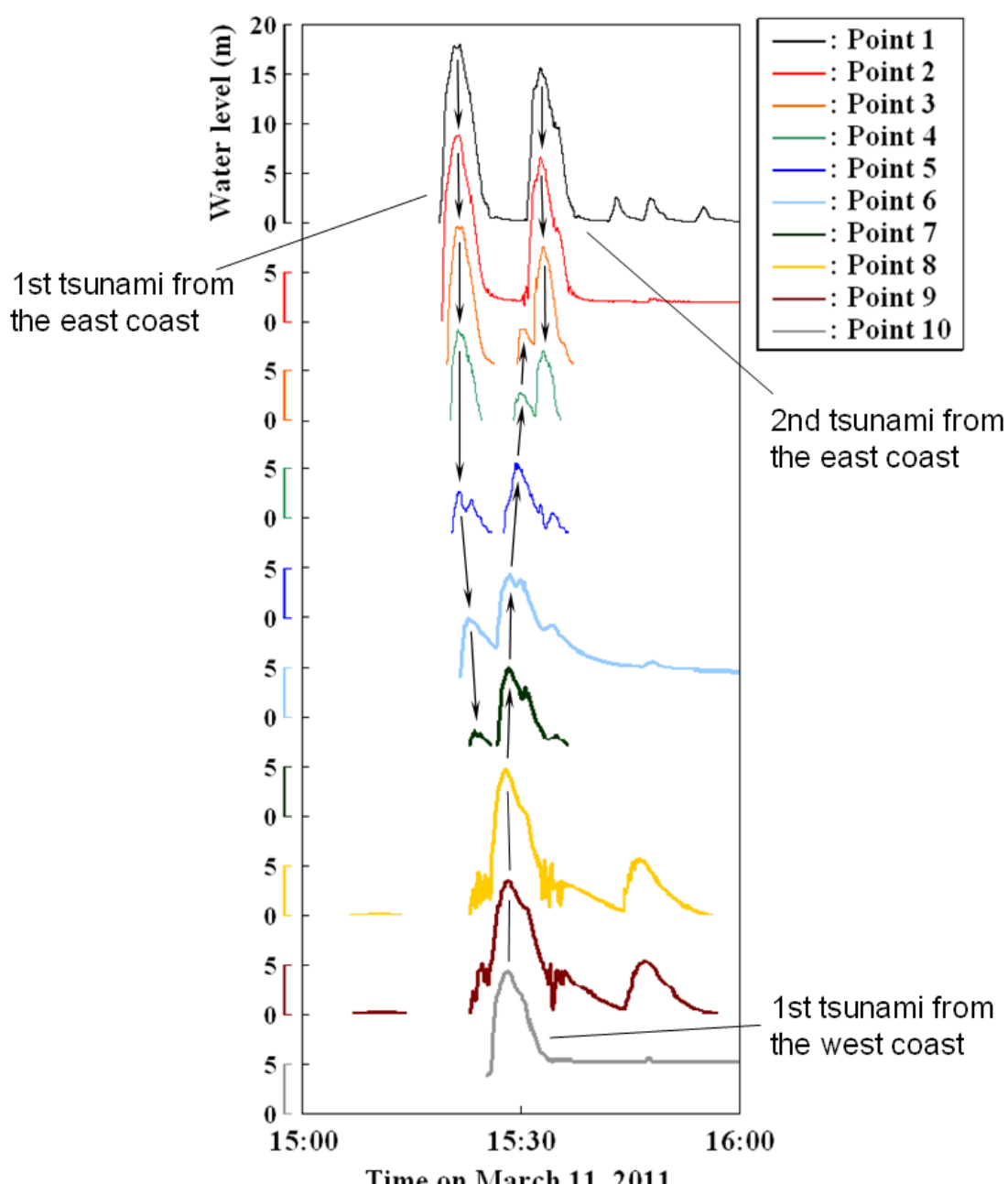

Fig. 13. Numerical result of time variation in water level at each point indicated in Fig. 12.

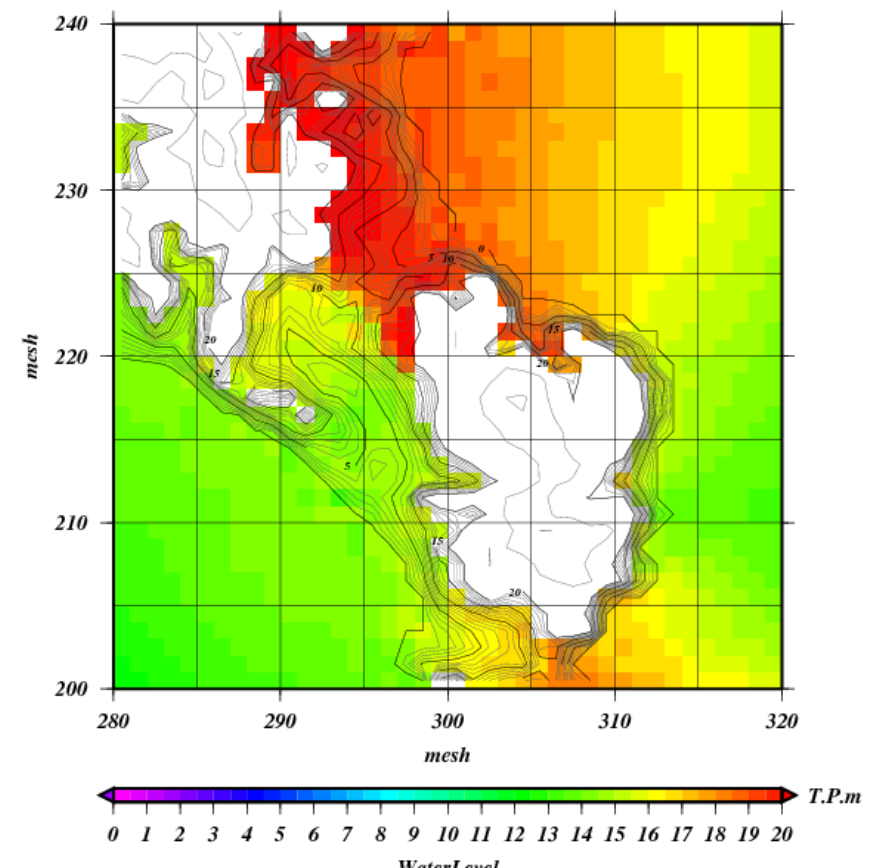

Fig. 14. Numerical result of the maximum inundation height in the area shown in Fig. 12. 


\section{CONCLUSIONS}

The field survey results obtained in the north of Miyagi Prefecture were summarized referring to a part of the survey results by other teams of the JSG. The inundation height in both Kesennuma City and Minamisanriku Town was generally larger at bay heads and promontory tips except several points including both the Kesennuma Port area sheltered by Karakuwa Peninsula and Akaushi having a tapering area. The steel frame buildings revealed their fragility around Shizugawa Bay, where the tsunamis reached inland far away from the sea along valleys and rivers. The inundation height was generally higher in the east than in the west of Oshika Peninsula in the east of Ishinomaki City. It should be noted that many reinforced concrete buildings were collapsed in Onagawa Town. The first tsunami from the west coast and the second tsunami from the east coast should come together in Utatsusaki Peninsula according to the numerical simulation, which is consistent with the interviews to survivors. It is both syntheses of general damage and analyses of local characteristics that are important to achieve community reconstruction.

\section{ACKNOWLEDGMENTS}

The authors are deeply grateful to the local people in the affected areas who gave us precious reports about the disaster. The survey of the authors could not be carried out without the support of instrument arrangement etc. by Prof. T. Hosoyamada, Nagaoka University of Technology.

\section{REFERENCES}

Arakawa, A. and V.R. Lamb. 1977. Computational design of the basic dynamical processes of the UCLA general circulation model, Methods in Computational Physics, 17, Academic Press, New York, 173-265.

Imamura, F., S. Koshimura, R. Ooya, Y. Mabuchi and Y. Murashima. 2011. Tohoku University model (version 1.0), http://www.tsunami.civil.tohoku.ac.jp/hokusai3/J/events/tohoku_2011/model/, 1-12 (in Japanese).

Iwasaki, T. and A. Mano. 1979. Numerical simulation of two-dimensional tsunami runup by Euler's coordinates, Proc. 26th Japanese Conf. on Coastal Eng., 70-74 (in Japanese).

Kawai, H., M. Satoh, K. Kawaguchi, and K. Seki. 2011. Characteristics of the 2011 off the Pacific Coast of Tohoku Earthquake Tsunami, Report of the Port and Airport Research Institute, 50, No. 4, 3-63 (in Japanese).

Mansinha, L. and D.E. Smylie. 1971. The displacement fields of inclined faults, Bull. the Seismological Soc. of America, 61, 1433-1440.

Mikami, T., T. Shibayama, M. Esteban, and R. Matsumaru. 2012. Field survey of the 2011 Tohoku Earthquake and Tsunami in Miyagi and Fukushima Prefectures, Coastal Engineering Journal, 54(1), Special Issue of 2011 Tohoku Tsunami.

Mori, N., T. Takahashi, T. Yasuda and H. Yanagisawa. 2011. Survey of 2011 Tohoku earthquake tsunami inundation and run-up, Geophysical Research Letters, 38, 6pp., L00G14, doi:10.1029/ 2011 GL049210.

Mori, N., T. Takahashi and The 2011 Tohoku Earthquake Tsunami Joint Survey Group. 2012. Nationwide post event survey and analysis of the 2011 Tohoku Earthquake Tsunami, Coastal Engineering Journal, 54(1), Special Issue of 2011 Tohoku Tsunami.

Suppasri, A., S. Koshimura, K. Imai, E. Mas, H. Gokon, A. Muhari and F. Imamura. 2012. Field survey and damage characteristic of the 2011 East Japan Tsunami in Miyagi Prefecture, Coastal Engineering Journal, 54(1), Special Issue of 2011 Tohoku Tsunami.

The 2011 Tohoku Earthquake Tsunami Joint Survey Group. 2011. http://www.coastal.jp/tsunami2011/. 